\title{
Original Intent and the Sherman Antitrust Act: A Re-examination of the Consumer-Welfare Hypothesis
}

\author{
Christopher Grandy
}

An important tenet of the Chicago School of antitrust asserts that the Sherman Act's framers sought to foster consumer welfare. This article challenges that interpretation by re-examining the legislative history. That history suggests that a consumer-welfare standard did not survive the legislative process and that, if anything, Congress focused on the behavior of producers.

$\mathbf{I}^{\mathrm{n}}$

n 1966 Judge Robert Bork published an article in The Journal of Law $\&$ Economics titled "Legislative Intent and the Policy of the Sherman Act." Bork argued that the bills and debates preceding adoption of the Sherman Antitrust Act of 1890 clearly indicated that Congress intended the measure to enhance consumer welfare. Since then, the "Chicago School" of antitrust has carried the day in both academic and public policy circles, and the conventional wisdom has incorporated Bork's view of the Sherman Act. ${ }^{1}$ In this article I re-examine the Act's legislative history, taking exception to Bork's view and argue that, of the variety of goals expressed in the debates, Congress appeared to reject consumer welfare. If anything, Congress seemed more concerned with producer, rather than consumer, welfare.

The widespread acceptance of Bork's perspective flies in the face of a large literature on antitrust's history that identifies a bewildering variety of goals. Some argue that the political content of antitrust was at least as important as its economic content. ${ }^{2}$ Important histories of antitrust note the shift in contemporary public concern about monopolies from abuse of governmental power to abuse of private power. ${ }^{3}$ The

The Journal of Economic History, Vol. 53, No. 2 (June 1993). (C) The Economic History Association. All rights reserved. ISSN 0022-05070.

The author is Assistant Professor of Economics, Barnard College, New York, NY 10027 and Visiting Assistant Professor of Economics, University of Hawaii, Honolulu, HI 96822.

For comments on this paper I wish to thank Roger Blair, Duncan Foley, Herbert Hovenkamp, Sumner La Croix, Gary Libecap, and attenders of the Faculty Seminar in Economics at the University of Hawaii. I also thank the editor for improving the clarity and tone of the argument. The usual caveat applies.

${ }^{1}$ Hovenkamp, "Chicago," p. 1020; Schmidt and Rittaler, Critical Evaluation, pp. xvii, 20; and Posner, Antitrust Law, p. 20.

2 Blake and Jones, "Defense," pp. 383, 394; Blake and Jones, "Three-Dimensional," p. 430; Flynn, "Reagan Administration's," pp. 295, 304; Millon, "Sherman Act,” pp. 1220, 1224, 1227, 1241, 1247; Sklar, Corporate Reconstruction, pp. 265-66, 282, 298; May, “Antitrust,” p. 297; and Freyer, Regulating, pp. 9, 60-61, 85.

3 Thorelli, Federal Antitrust, p. 290; Letwin, "Congress," p. 226; and Letwin, Law, p. 59. See also Millon, "Sherman Act," p. 1224; May, "Antitrust," pp. 259, 283; and Lande, "Wealth Transfers," p. 83. 
protection of small independent business arises repeatedly in discussions of antitrust's goals. ${ }^{4}$ Related to this is the notion that antitrust sought to ensure "fair competition." A number of authors, writing from a public choice perspective, have argued that the Sherman Act follows other regulatory efforts in displaying a strong private interest component. ${ }^{6}$ Robert H. Lande stood Bork's argument on its head by suggesting that instead of an implicit efficiency goal, Congress intended to effect a pure transfer from producers to consumers. ${ }^{7}$ With the possible exception of Lande, these authors suggest that Congress focused on producers, rather than consumers, as the object of legislation. This article therefore re-evaluates the legislative history of the Sherman Act in challenge to Bork's contention that the record reflects a consumer-welfare standard. ${ }^{8}$

\section{THE CONSUMER-WELFARE HYPOTHESIS}

For Robert Bork, antitrust law should primarily protect and enhance consumer welfare. By "consumer welfare" Bork meant something akin to "net consumer surplus," but the correspondence is not exact. Bork advocated minimizing allocative inefficiency, subject to adjustment for increases in productive efficiency. For example, consider a merger that bestows market power on the surviving entity. Relative to the market conditions before the merger, Bork would regard any emerging deadweight loss as undesirable. But he would allow the merger to the extent that the new entity could lower costs to the point that total cost savings exceeded the deadweight loss. Thus, changes in productive efficiency may offset changes in allocative efficiency. ${ }^{9}$

Bork argued that the debates on the Sherman Antitrust Act revealed

${ }^{4}$ Thorelli, Federal Antitrust, pp. 351, 608; Blake and Jones, "Three-Dimensional," pp. 429, 431; Dewey, "Economic Theory," p. 434; McCraw, "Rethinking," pp. 25, 29, 46-48; Lande, "Wealth Transfers," pp. 104, 120-21, 139; Hovenkamp, "Antitrust Policy," pp. 219, 242; Flynn, "Reagan Administration's," p. 296; Sklar, Corporate Reconstruction, pp. 33, 77, 85, 110; Carey, "Sherman Act," p. 352; May, "Antitrust," pp. 265, 274-75; and Schmidt and Rittaler, Critical Evaluation, pp. xvii, 64. Critics of small-business protection as a legitimate antitrust goal include Bork and Bowman, "Crisis," p. 369; Blake and Jones, "Defense," pp. 380, 398; Posner, Antitrust Law, p. 106; Bork, Antitrust Paradox, pp. 54, 56; and DiLorenzo, "Origins," p. 85.

s Dewey, Monopoly, p. 144; Dewey, "Economic Theory," pp. 429-30; Lande, "Wealth Transfers," pp. 95, 101, 115; Flynn, "Reagan Administration's," pp. 283-84, 287; May, "Antitrust," p. 333; Scherer, "Efficiency," p. 248; and Freyer, Regulating, p. 113. See Bork's criticism of this view in Bork, "Legislative Intent," pp. 11-12; and Bork, "Antitrust," pp. 251-52.

${ }^{6}$ Dewey, Monopoly, p. 309; DiLorenzo, "Origins," p. 74; Hazlett, "Legislative History," p. 264; and Libecap, "Chicago Packers," pp. 255-58. Freyer, Regulating, pp. 18, 40-41, notes the threat to small business created by the revolutions in technology and organization documented in Chandler, Visible Hand, and Lamoreaux, Merger Movement.

7 Lande, "Wealth Transfers."

${ }^{8}$ The Appendix gives a chronology of Sherman's bill through the 50th and 51st Congresses. In support of a theoretical analysis, Hovenkamp, "Antitrust's Protected Classes," pp. 21-30, reviewed the legislative history of the Sherman Act in less detail and came to similar conclusions.

${ }^{9}$ Bork, Antitrust Paradox, pp. 107-10. 
a primary concern for consumer welfare. ${ }^{10}$ Bork recognized that the debates suggested a number of goals, but he argued that in each case Congressmen only advocated other goals to an extent consistent with consumer welfare. " "Not only was consumer welfare the predominant goal expressed in Congress but the evidence strongly indicates that, in case of conflict, other values were to give way before it." 12

The distinction between "monopolize" and "monopoly" played an important role in Bork's argument. Section 2 of the Sherman Act forbids any person to monopolize, or attempt to monopolize, trade or commerce. The force of this section lies in its application to an individual, rather than to a conspiracy or agreement among individuals. The terminology also emphasizes the process of acquiring control over the market-not the fact of monopoly-as central to the offense. Bork interpreted this section to exempt organizations that acquire monopoly power through legitimate means-that is, via superior efficiency. ${ }^{13}$ Indeed, Bork stressed the importance of an exchange between Senators John E. Kenna (D., West Virginia), George F. Edmunds (R., Vermont) and George F. Hoar (R., Massachusetts). ${ }^{14}$ Kenna asked whether the proposed act would apply to someone who became the only seller of a product solely through superior business practice. The conclusion of the exchange, that this case would not fall within the act, strongly suggested to Bork that Congress intended to exempt agreements, contracts, and organizations that promoted economic efficiency, and that this implied Congress favored a consumer-welfare standard.

The asserted equivalence of the phrases "restraint of trade or commerce" and "restriction of output" constituted a second important element in Bork's argument. The common law had long proscribed agreements or combinations to "restrain trade," and the bills and debates preserved this phraseology. Bork argued that Sherman used the phrase "restraint of trade" as a synonym for "restriction of output."15 Thus, he interpreted Sherman's suggestion that the courts "will distinguish between lawful combinations in aid of production and unlawful combinations to prevent competition and in restraint of trade," as a distinction between combinations that enhance efficiency and those that restrict output. ${ }^{16}$ Bork argued that since restrictions of output tend to

\footnotetext{
${ }^{10}$ Scherer, "Efficiency," criticized the suggestion that contemporary economists objected to combinations on the basis of allocative inefficiency. Lande, "Wealth Transfers," pp. 86-87, went so far as to suggest that most economists did not understand the concept.

11 Bork, “Legislative Intent," p. 10.

12 Ibid.

13 Ibid., p. 29.

14 Ibid., pp. 28-31.

15 Ibid., pp. 16, 36.

${ }^{16}$ Kintner, Legislative History, p. 115; and Congressional Record Mar. 21, 1890, p. 2456. Bork, “Legislative Intent,” p. 36.
} 
raise prices, thereby harming consumers, the prohibition of restraints of trade indicated a consumer welfare goal.

Judge Bork's interpretation required the rejection of state common law as the basis of the Sherman Act. State common law originated in England and evolved in a way that focused on agreements and combinations in restraint of trade. ${ }^{17}$ The overwhelming number of cases involved contracts or combinations of individuals to prevent someone from practicing his trade or business. The doctrine almost always focused on the producer, not the consumer. Thus, a common-law interpretation undermined Bork's position. Bork argued that Sherman stated a highly selective version of the common law that supported a consumer-welfare standard. ${ }^{18}$

\section{THE LEGISLATIVE DEBATE}

\section{Consumer Welfare As Primary Goal}

In general, ample evidence exists to support Judge Bork's claim that the legislative history of the Sherman Act reveals a concern for consumers. References to output restrictions and price increases emerge in the debates, and the goal of reducing the cost of goods to consumers appears explicitly in most of the early bills. The relation of the trust issue to the debate on tariffs also suggests that legislators regarded consumer welfare as important. But as the debate evolved, Congress apparently abandoned concern for the consumer in favor of other goals. The desire of legislators to regulate or rationalize business behavior appears independently in the debates and is revealed in some of the very evidence used to argue for the primacy of a consumerwelfare standard. The bills never mentioned protecting consumers without also mentioning protecting producers via the regulation of competition. Moreover, references in the bills to the effects of combinations on prices came under sharp attack in the debates and ultimately disappeared from the final legislation. In short, the legislative record undermines Bork's interpretation. ${ }^{19}$

Evidence that Congressmen worried about price increases to consumers comes from the antitrust bills themselves, statements in debate, and concerns about the relation of the tariff to the trust issue. In addition to other bills, Sherman's S. 3445 read in part, "all arrangements, contracts, agreements, trusts, or combinations between persons or corpo-

\footnotetext{
${ }^{17}$ For discussions of the common-law sources of American antitrust law, see Taft, Anti-trust Act; Dewey, Monopoly, chaps. 9, 10; and Letwin, Law. The most recent analysis of common-law trade restraints, though with relatively little U.S. emphasis, is Trebilcock, Common Law.

${ }^{18}$ Bork, "Legislative Intent," pp. 37-39.

19 Earl W. Kintner has compiled the legislative history of American antitrust law in a multivolume work, Legislative History, cited hereafter as Kintner, $L H$. In the following discussion of the legislative history, I cite both Kintner and the Congressional Record (cited hereafter as Cong. Rec.).
} 
rations designed, or which tend, to advance the cost to the consumer ... are hereby declared to be against public policy, unlawful, and void. . ."20 All iterations of Sherman's bill preserved language referring to cost increases to the consumer until the Senate Judiciary Committee reported the revision on April 2, 1890, that eventually became law. Among statements in debate expressing a consumerwelfare theme was Sherman's reference to corporations such as Standard Oil. "If they conducted their business lawfully, without any. attempt by these combinations to raise the price of an article consumed by the people of the United States, I would say let them pursue that business." 21 Many legislators, primarily Democrats, pointed to the tariff as the source of trusts' powers to raise prices. ${ }^{22} \mathrm{~A}$ few who supported the tariff even suggested that it somehow protected consumers by keeping out international trusts. ${ }^{23}$

Yet in both the bills and debates an independent concern for fair competition challenged the primacy of a consumer-welfare motivation. No bill expressed a consumer-welfare concern without making independent reference to the preservation of free and fair competition or trade. For example, Sherman's S. 3445 contained a clause preceding that just quoted: "[t]hat all arrangements, contracts, agreements, trusts, or combinations between persons or corporations made with a view, or which tend, to prevent full and free competition in the production, manufacture, or sale of articles of domestic growth or production ... are hereby declared to be against public policy, unlawful, and

${ }^{20}$ Kintner, $L H$, p. 63, emphasis added. See also Reagan's S. 3440 of the 50th Congress in Kintner, $L H$, p. 61 and Hoar's amendment to Sherman's $S .3445$ providing recovery in civil action for damages due to price increases (Kintner, $L H$, p. 67 ).

${ }^{21}$ Kintner, $L H$, p. 177; and Cong. Rec., Mar. 24, 1890, p. 2569. See also statements by George on price increases and objecting to the effectiveness of civil suits to remedy small consumer losses due to price increases (Kintner, LH, pp. 99, 100; and Cong. Rec., Feb. 27, 1890, pp. 1767, 1768). George repeated such objections to the final bill, arguing that to the extent Congress offered it as relief to the consumer, the law was a sham (Kintner, $L H$, p. 289; and Cong. Rec., Apr. 8, 1890, p. 3150). Combined with the near-unanimous passage of the final bill in both houses, George's objections suggest the bill may not have been offered as relief to consumers.

${ }^{22}$ See comments by Senators George (Kintner, LH, pp. 98, 100, 111, 184, 278; Cong. Rec., Feb. 27, 1890, pp. 1767, 1768, 1772; Cong. Rec., Mar. 25, 1890, p. 2598; and Cong. Rec., Apr. 2, 1890, p. 2901), Vest (Kintner, LH, pp. 137, 139; and Cong. Rec., Mar. 21, 1890, pp. 2465, 2466), and Vance (Kintner, LH, p. 235; and Cong. Rec., Mar. 26, 1890, p. 2647). See also comments by Representatives Culberson (Kintner, LH, p. 305; and Cong. Rec., May 1, 1890, p. 4091), W. L. Wilson (Kintner, $L H$, pp. 309-11; and Cong. Rec., May 1, 1890, pp. 4093-94), and Adams (Kintner, $L H$, p. 311 ; and Cong. Rec., May 1, 1890, p. 4094). Legislators introduced provisions that directed the president to suspend tariffs on goods produced by trusts (Kintner, LH, pp. 180, 249, 313; Cong. Rec., Mar. 24, 1890, p. 2570; Cong. Rec., Mar. 26, 1890, p. 2657; and Cong. Rec., May 1, 1890, p. 4098).

${ }^{23}$ Comments by Senator Dawes (Kintner, $L H$, pp. 139-40; and Cong. Rec., Mar. 21, 1890, p. 2466) and Representative E. B. Taylor (Kintner, LH, pp. 314, 315; and Cong. Rec., May 1, 1890, p. 4098). See related comments by Senator Allison (Kintner, LH, pp. 146-48; and Cong. Rec., Mar. 21, 1890, pp. 2470-71). 
void. . . ",24 All subsequent versions of Sherman's bill preserved this independence until the Senate Judiciary Committee reported its revision. ${ }^{25}$ The existence of separate clauses suggests that preserving full and free competition meant something other than maximizing consumer welfare. Sherman's comments in debate also reflected this independent concern for the competitive process. "[Courts must intervene] when [corporations] combine with a purpose to prevent competition, so that if a humble man starts a business in opposition to them, solitary and alone, . . . they will crowd him down and they will sell their product at a loss or give it away in order to prevent competition. . .,"26 Finally, some legislators appeared to reject consumer welfare outright. Senator Edmunds warned against trusts that seductively lowered prices while destroying the public welfare, and Representative William E. Mason (R., Illinois) argued that no reduction of price could justify driving "honest men from legitimate business enterprises." 27

Much of the resistance to Sherman's bill reflected discomfort with its apparent condemnation of even "reasonable" price coordination. And this discomfort reflected a concern for producers rather than consumers. Senator William M. Stewart (R., Nevada) argued that the blanket condemnation of price and output coordination "would probably, if carried out literally, in times of depression, break up half the manufac-

${ }^{24}$ Kintner, $L H$, p. 63. Senator Reagan's S. 3440 of the 50 th Congress defined illegal trust activities as either increasing or decreasing prices (Kintner, $L H$, p. 61; and Cong. Rec., Aug. 14, 1888 , p. 7512). Also see independent references to promoting fair trade in the amendments of Senators Hoar (Kintner, $L H$, p. 67) and Coke (Kintner, $L H$, p. 209). Bork, "Legislative Intent," p. $15, \mathrm{fn} .11$, argued that the phrase supported consumer welfare, but such a reading ignores the explicit independence of the clauses that suggests something more than redundancy. Further, as Hovenkamp, Enterprise, pp. 273-74, noted, for the first neoclassical economists that would have had any influence on the Sherman Act, "[a]nticompetitive conduct was a restraint on individual freedom, not mere interference with a relationship between prices and costs."

${ }^{25}$ See S. 3445 As Reported by the Senate Committee on Finance, 50th Cong., 1st sess., Sept. 11, 1888 (Kintner, LH, p. 64); S. 1, 51st Cong., 1st sess., Dec. 4, 1889 (Kintner, LH, p. 89); Amendment to S. 1 As Reported by the Senate Committee on Finance, 51st Cong., 1st sess., Mar. 18, 1890 (Kintner, $L H$, p. 112); S. 1 As Amended by the Senate, 51 st Cong., 1st sess., Mar. 25, 1890 (Kintner, LH, p. 214); and S. 1 As Amended by the Senate, 51st Cong., 1st sess., Mar. 26, 1890 (Kintner, $L H$, p. 256).

${ }^{26}$ Kintner, $L H$, p. 177; and Cong. Rec., Mar. 24, 1890, p. 2569. Also see Sherman's related comments (Kintner, $L H$, p. 116; and Cong. Rec., Mar. 21, 1890, p. 2457) as well as those of Senators George (Kintner, $\mathbf{L H}$, pp. 77, 99, 100, 184, 284; Cong. Rec., Feb. 4, 1889, p. 1458; Cong. Rec., Feb. 27, 1890, pp. 1767, 1768; Cong. Rec., Mar. 25, 1890, p. 2598; and Cong. Rec., Apr. 8, 1890, p. 3147), Platt (Kintner, LH, pp. 271-72; and Cong. Rec., Mar. 27, 1890, pp. 2729-30), and Rep. E. B. Taylor (Kintner, LH, p. 315; and Cong. Rec., May 1, 1890, p. 4098). Bork, "Legislative Intent," pp. 41-42, recognized George's proproducer statements, but argued these were consistent with consumer welfare. I think it significant that George expressed an independent concern for producers.

${ }^{27}$ For Edmund's statement, see Kintner, LH, pp. 264-65; and Cong. Rec., Mar. 27, 1890, p. 2726; for Mason's, see Kintner, $L H$, p. 318; and Cong. Rec., May 1, 1890, p. 4100. Bork, "Legislative Intent," pp. 42-43, fn. 104, suggested that Edmunds referred to predatory pricing, consistent with a consumer welfare concern, but reference to predatory pricing is also consistent with a producer-welfare notion. In the same footnote Bork acknowledged Mason's comment as inconsistent with consumer welfare. 
turing establishments in the country." 28 The proposed exemption for farmers and labor that Sherman introduced as an amendment on March 25,1890 , also indicated concern about a universal condemnation of price coordination. ${ }^{29}$ At least for these groups, legislators supposedly espousing a consumer-welfare standard intended to grant a significant exception. ${ }^{30}$ Senator Edmunds seemed to question the entire attempt to legislate by reference to prices in opposing the exemption for farmers and labor. He pointed to the anomaly of prohibiting combinations of capital because they threatened to raise prices, while protecting combinations of labor that would have the same effect. ${ }^{31}$

Discussion of the efficiencies of large-scale organization cast further doubt on the consumer-welfare hypothesis and indicate that Sherman did not view efficiency as an antitrust defense. Several senators expressed objections to Sherman's bill on the grounds that it would impede the efficiency-promoting effects of combinations. ${ }^{32}$ On March 26, 1890, Senator Nelson W. Aldrich (R., Rhode Island) sought to insert the following proviso into the first section of Sherman's S. 1:

That this act shall not be construed to apply to . . combinations . . made with a view or which tend, by means other than by a reduction of the wages of labor, to lessen the cost of production or reduce the price of any of the necessaries of life, nor to the combinations ... made with a view ... to increase the earnings of persons engaged in any useful employment. ${ }^{33}$

This amendment permitted combinations to justify their actions to the extent they sought to lower production costs. It essentially stated the productive efficiency view advocated by Judge Bork. Indeed, Bork asserted that Aldrich's amendment accorded with Sherman's position and that its adoption by the Senate indicated that body's concurrence

\footnotetext{
${ }^{28}$ Kintner, $L H$, p. 199; and Cong. Rec., Mar. 25, p. 2606. Also see Stewart's related comments in Kintner, $L H$, pp. 167, 199, 226-29; Cong. Rec., Mar. 24, 1890, p. 2565; Cong. Rec., Mar. 25, 1890, p. 2606; and Cong. Rec., Mar. 26, 1890, pp. 2643-44. Bork, "Legislative Intent," p. 23, apparently following Thorelli, Federal Antitrust, pp. 190-91, asserted that "[t]he Senate paid no attention" to Stewart, although he provided no evidence for the assertion.

29 Kintner, $L H$, pp. 205-6; and Cong. Rec., Mar. 25, 1890, p. 2611. Senator George objected to the bill's application to farmers and labor (Kintner, $L H$, pp. 78-80; and Cong. Rec., Feb. 4, 1889, pp. 1458-59), and Sherman denied the intention to apply the bill to those groups (Kintner, $L H$, pp. 79, 162; Cong. Rec., Feb. 4, 1889, p. 1458; and Cong. Rec., Mar. 24, 1890, p. 2562). Also see Senator Reagan's comments in Kintner, $L H$, p. 161; and Cong. Rec., Mar. 24, 1890, p. 2562.

${ }^{30}$ Bork, "Legislative Intent," p. 31, suggested that the failure of the exemption to appear in the final bill supported the consumer welfare standard. As argued later, I believe that the Senate Judiciary Committee's version rejected a consumer welfare standard, and the absence of the farm and labor exemption was merely part of the rejection of a focus on prices.

${ }^{31}$ Kintner, $L H$, pp. 266-67; and Cong. Rec., Mar. 27, 1890, p. 2727; also see comments by Rep. Stewart (Kintner, $L H$, p. 341; and Cong. Rec., June 11, 1890, p. 5956).

${ }^{32}$ See the comments of Senators Hoar and Reagan (Kintner, LH, p. 68; and Cong. Rec., Jan. 25, 1889, p. 1167) and of Senator Stewart (Kintner, LH, pp. 167, 200; Cong. Rec., Mar. 24, 1890, p. 2564; and Cong. Rec., Mar. 25, 1890, p. 2606). Sherman also seemed to recognize the potential economies of corporate organization (Kintner, $L H$, p. 116; and Cong. Rec., Mar. 21, 1890, p. 2457).

${ }^{33}$ Kintner, $L H$, p. 245; and Cong. Rec., Mar. 26, 1890, pp. 2654-55. Emphasis added.
} 
with Sherman's views. ${ }^{34}$ Sherman seemed inclined to accept all proposed amendments to his bill in the interest of getting it past the Senate. ${ }^{35}$ Yet he vigorously objected to the Aldrich amendment, arguing that it "practically fritters away the substantial elements of this bill."36 Sherman seemed to recognize the ease with which defendants could claim to promote efficiency and thereby escape the sanctions of his bill. ${ }^{37}$

Repeated efforts to refer Sherman's bill to the Senate Judiciary Committee failed in late March 1890 until Senator Orville H. Platt (R., Connecticut) delivered an impassioned speech denouncing the breadth of S. 1. Over the week between March 21 and 27, 1890, the Senate, acting as a committee of the whole, added a variety of amendments to Sherman's bill, resulting in repeated motions to refer the bill to the Judiciary Committee. ${ }^{38}$ Sherman, among others, opposed these motions and they were defeated. ${ }^{39}$ Toward the end of debate on March 27, 1890, Senator Platt delivered a speech strongly critical of the scope of S. 1, "[this bill] is aimed at every business and every business transaction in the United States. . . "40 Platt echoed the concerns of others about explicit reference to prices. "I am entirely sick of this idea that the lower the prices are the better for the country, and that any effort to advance prices, no matter how low they may be, and that any arrangement between persons engaged in business to advance prices, no matter how low they may be, is a wrong and ought to be repressed and punished." 41 If the Senate would not refer the bill to committee, Platt argued for voting the bill down rather than proceeding. At that point Senator C. Walthall (D., Mississippi) moved that the Senate refer the bill to the Judiciary Committee. Sherman made no objection, and the motion passed by a vote of 31 to $28 .{ }^{42}$

The course of this debate, and the version of Sherman's bill that emerged from the Judiciary Committee less than a week later, strongly suggest that, if anything, the Senate rejected a consumer-welfare standard. Directly, and through the support for the farm and labor exemption, senators repeatedly questioned the wisdom of regulating by

${ }^{34}$ Bork, “Legislative Intent," p. 28.

${ }^{35}$ Kintner, $L H$, p. 198; and Cong. Rec., Mar. 25, 1890, p. 2605.

${ }^{36}$ Kintner, $L H$, p. 264; and Cong. Rec., Mar. 27, 1890, p. 2726.

${ }^{37}$ Bork did not mention Sherman's objection.

${ }^{38}$ Kintner, LH, pp. 183, 184, 246; Cong. Rec., Mar. 24, 1890, p. 2572; Cong. Rec., Mar. 25, 1890 , p. 2597; and Cong. Rec., Mar. 26, 1890, p. 2655.

${ }^{39}$ Kintner, $L H$, pp. 189, 192, 196, 198, 200-201, 204, 247; Cong. Rec., Mar. 25, 1890, pp. 2601, 2602, 2604, 2605, 2606, 2608; and Cong. Rec., Mar. 26, 1890, p. 2655. Senator Shelby M. Cullom moved to refer the bill back to the Committee on Finance, in which Sherman served, but this motion also failed (Kintner, $L H$, p. 252, 254; and Cong. Rec., Mar. 26, 1890, pp. 2659, 2661).

${ }^{40}$ Kintner, $L H$, p. 271 ; and Cong. Rec., Mar. 27, 1890, p. 2729. See also Kintner, $L H$, p. 273; and Cong. Rec., Mar. 27, 1890, p. 2730.

${ }^{41}$ Kintner, $L H$, pp. 271-72; and Cong. Rec., Mar. 27, 1890, p. 2729.

${ }^{42}$ Kintner, $L H$, p. 274; and Cong. Rec., Mar. 27, 1890, p. 2731. 
reference to prices. Any attempt to regulate activity affecting prices or output-including advancing a consumer-welfare goal-potentially threatened legitimate economic activity. Platt's forceful expression of these doubts led immediately to referral of the bill to the Judiciary Committee. ${ }^{43}$ The Committee reported an S. 1 on April 2, 1890, that struck the original language and substituted its own. In particular, Section 1 deleted both references to the prevention of "full and free competition" and to a tendency to "advance the cost to the consumer." Instead, the revision declared illegal "[e]very contract, combination in the form of trust or otherwise, or conspiracy, in restraint of trade or commerce among the several States, or with foreign nations...." Section 2 introduced a new issue by making illegal any attempt to "monopolize" any part of interstate or foreign commerce. The revised bill also deleted the exemption for farmers and labor, eliminated Senator Aldrich's amendment providing a defense of lowering production costs, and eliminated explicit language granting consumers a civil remedy for damages due to price increases. ${ }^{44}$ The revision passed the Senate on a vote of 52 to 1 with 29 absent and eventually passed the House on a vote of 242 to zero with 85 not voting. This history simply fails to support the consumer-welfare hypothesis. Instead, Congress chose language well defined in the common law-a choice that, in light of the debates, suggested a desire to "regulate" business conduct and to promote "fair" competition in trade and production. The language directly dealt with producers and their behavior, not with consumers.

\section{"Monopolize" Versus "Monopoly"}

Judge Bork argued that the only substantial debate on Section 2 (prohibiting attempts to monopolize) indicated that the Judiciary Committee sought to exempt acquisitions of market control achieved through superior efficiency. ${ }^{45}$ Yet the definition of the monopolization offense that came out of that debate makes clear that the Judiciary Committee members saw competitors as the primary victims, not consumers.

The discussion that arose from questions posed by Senator Kenna appears at first sight to support Bork's position on the meaning of Section 2. On April 8, 1890, Kenna rose to ask, "Is it intended by the committee, as the [second] section seems to indicate, that if an individual . . . by his own skill and energy . . . shall pursue his calling in such a way as to monopolize a trade, his action shall be a crime under

\footnotetext{
${ }^{43}$ Curiously, Bork, "Legislative Intent," p. 23, asserted without explanation that the "Senate paid no attention" to Platt. Thorelli, Federal Antitrust, p. 226, made the same assertion, emphasizing Platt's unusual doubts about competition's virtues. Yet Thorelli's discussion made clear his view of competition as meaning freedom of opportunity for producers, not necessarily the advancement of consumer welfare.

${ }^{44}$ Kintner, $L H$, pp. 275-77.

${ }^{45}$ Bork, "Legislative Intent," pp. 28-30.
} 
this proposed act?",46 Kenna proceeded to ask whether the act would punish, for example, a Kentucky dealer in shorthorn cattle who, "by virtue of his superior skill," acquired all the business. Senator Edmunds, chair of the Judiciary Committee, replied that the act would not apply in this case. For Bork, this implied that the Committee intended to exempt monopoly acquired by "superior skill" (that is, through efficiency). Bork asserted that monopoly acquired by any means would tend to hurt small rivals, whereas efficient monopolies would tend to advance consumer welfare. ${ }^{47}$ Thus, he viewed the exemption for efficient monopolies as support for the consumer-welfare standard. ${ }^{48}$

Yet this discussion elicited a definition of "monopoly" with a somewhat different implication. Edmunds denied that the hypothetical Kentucky shorthorn cattle dealer fell within the definition of "monopoly" at all. The dealer may be the sole seller, but "[h]e has not bought off his adversaries. He has not got the possession of all the horned cattle in the United States. He has not done anything but compete with his adversaries in trade. . ."49 Senator Hoar claimed to have raised Kenna's question in committee and was convinced that monopoly bore a technical meaning. "It is the sole engrossing to a man's self by means which prevent other men from engaging in fair competition with him. "50 By implication, since the Kentucky cattle dealer did nothing to prevent competition from others, he could not have "monopolized" the trade.

Contrary to Bork, the stress of these remarks on the activities of individuals supported a focus on producers rather than consumers. ${ }^{51}$ These responses undermine Bork's assertion that monopoly gained by efficiency hurts rivals. For Edmunds and Hoar, the definition of monopoly depended on exclusion of others from the market; an "efficient monopoly" cannot hurt small rival producers by definition. Had the efficient Kentucky shorthorn cattle dealer acquired his position in the market by preventing "other men from engaging in fair competition," Edmunds and Hoar would have opposed his exemption from the act. Section 2 emphasized the method of competing and the means of attaining market power, not the efficiency of the resulting combina-

46 Kintner, LH, p. 292; and Cong. Rec., Apr. 8, 1890, p. 3151.

${ }^{47}$ Bork, "Legislative Intent," p. 30.

${ }^{48}$ DiLorenzo and High, "Antitrust," p. 424, suggested that contemporaries expressed concern about Section 2's application to efficiency-promoting activities.

${ }^{49}$ Kintner, LH, p. 292; and Cong. Rec., Apr. 8, 1890, pp. 3151-52.

${ }^{50} \mathrm{Kintner}, \mathrm{LH}$, p. 293; and Cong. Rec., Apr. 8, 1890, p. 3152; emphasis added.

${ }^{51}$ Bork, "Legislative Intent," p. 29, recognized the emphasis: "The wording [monopolize] itself suggests that an activity rather than a status was to be outlawed, and that in turn suggests that there were lawful means of gaining a monopoly position." For Bork, those lawful means meant superior zfficiency. I differ with Bork in concluding that the focus on activity directly concerns producers; :he consumer-welfare standard must be inferred through a questionable chain of reasoning, going irom emphasis upon activity to allowing efficient monopoly to the passing on of efficiency gains to :onsumers. 
tion. ${ }^{52}$ The language focused on producer activity as it affected other producers. ${ }^{53}$

\section{Restraint of Trade, Restriction of Output, and Common Law}

In arguing that Congress meant "restriction of output" by the phrase "restraint of trade," Bork denied the common-law basis for the Sherman Act. Bork had to take this position because in the common law agreements or combinations in restraint of trade had a meaning for state courts that cannot be reconciled with the consumer-welfare hypothesis. As a number of authors make clear, the application of this term nearly always referred to limiting or prohibiting someone from engaging in a particular trade or business. ${ }^{54}$ The common law distinguished between lawful and unlawful restraints of trade by the extent or reasonableness of the restraint. ${ }^{55}$ On the one hand, the potential purchaser of a business might balk if the seller could immediately start another, competing enterprise. On the other hand, the courts would not sanction a permanent restraint on an individual's ability to earn a living. The common law clearly applied the term "restraint of trade" to relations among producers.

Bork evaded the common-law meaning of "restraint of trade" by asserting that Congress relied on Sherman's highly selective view of the "common law," a view he claimed was entirely consistent with the consumer-welfare hypothesis. Bork noted that Sherman mingled his assertions about the common law with his proconsumer rhetoric. ${ }^{56}$ In his view, Sherman defined the common law for Congress and " $\mathrm{i}[\mathrm{t}]$ is to this 'common law,' holding full sway nowhere but in the debates of the Fifty-first Congress, that one must look to understand the Sherman Act." 57 Thus, for Bork, the Sherman Act's appeal to the common-law phrase "restraint of trade" in fact meant "restriction of output." 58 For

52 See Letwin, Law, p. 147; May, "Antitrust," pp. 292-94; and Sklar, Corporate Reconstruction, p. 418. Hovenkamp, “Distributive Justice," p. 18, put it this way: "Importantly, both the common law and the Fifty-first Congress drew the line between legal and illegal activity by looking not at how a monopoly was behaving, but by questioning how it had come into existence."

${ }^{53}$ As an aside, Bork, "Contrasts," pp. 401-2, and Posner, Antitrust Law, pp. 160, 173, challenged the notion that an individual can effectively monopolize the market, arguing that monopolization generally requires cooperation among competitors. Interestingly, Senator Gray offered an amendment that would have confined the operation of the Sherman Act to conspiracies among people. The Senate rejected this amendment after Edmunds noted that "we thought we had done the right thing in providing ... that if one person instead of two ... did it, it was just as offensive and injurious to the public interest as if two had combined to do it." See Kintner, $L H, \mathrm{pp}$. 292, 294; and Cong. Rec., Apr. 8, 1890, p. 3152.

${ }^{54}$ Dewey, Monopoly, chaps. 9, 10; Letwin, Law, p. 42; Sklar, Corporate Reconstruction, p. 104; and Taft, Anti-Trust Act, p. 15.

55 Dewey, Monopoly, pp. 123-25; Letwin, Law, p. 43; Sklar, Corporate Reconstruction, p. 98; and Taft, Anti-Trust Act, p. 20.

56 Bork, “Legislative Intent," pp. 37-38.

57 Ibid., pp. 37, 39.

58 Ibid., pp. 16 (fn. 16), 46. 
example, he interpreted the final bill's protections against "restraint of trade or commerce" as "safeguarding the flow of commerce against diminution, against, in a word, a restriction of output." 59

Even if one accepts Bork's characterization of Sherman's "common law," it is important to recognize that Sherman's influence over the content of the bill waned in the weeks before passage. Three days prior to referral of S. 1 to the Judiciary Committee, he angered his fellow senators with a speech that included the following: "If you are impotent and unable to deal with the question and can not prescribe any remedy but quack medicine [tariff reduction], then you are utterly unfit to perform your duties as the representatives of the people of the United States."60 That charge brought sharp reaction from a number of senators who objected to Sherman's presumption over the antitrust issue.$^{61}$ From this point, Sherman's power to shape the bill dwindled, culminating in its referral to the Judiciary Committee. ${ }^{62}$

The Senate Judiciary Committee's report of a bill dramatically different from the original suggests that its notion of the common law differed from the one Bork attributed to Sherman. Bork, however, denied the significance of the differences in the two versions of the bill, asserting that the brevity of the Senate debate and the fact that no senator explicitly objected to Sherman's common-law interpretation indicates that the Senate accepted his view of the law. ${ }^{63}$

The Judiciary Committee, however, was composed of the Senate's legal experts who presumably knew the "correct" version of the common law, and the members' own statements indicate that they intended that the bill they reported to the Senate (which ultimately became law) would enact the orthodox interpretation. Senator Edmunds, chair of the committee, explained that the members felt "we would frame a bill that should be clearly within our constitutional power, that we should make its definition out of terms that were well known to the law already, and would leave it to the courts in the first instance to say how far they could carry it. . ."64 Senator Hoar explained that "the great thing that this bill does, except affording a remedy, is to extend the common-law principles, which protected fair

s9 Ibid., pp. 33, 46.

${ }^{60}$ Kintner, LH, p. 176; and Cong. Rec., Mar. 24, 1890, p. 2569.

${ }^{61}$ See comments by Senator Vest (D., Missouri) in Kintner, LH, p. 179; and Cong. Rec., Mar. 24, 1890, p. 2570. See also comments by Senators Hoar (Kintner, LH, p. 179; and Cong. Rec., Mar. 24, 1890, p. 2570) and Teller (Kintner, LH, p. 181; and Cong. Rec., Mar. 24, 1890, p. 2571).

62 "The congressmen who drafted and passed the Sherman Antitrust Law thought they were merely declaring the illegality of offenses that the common law had always prohibited." Letwin, $L a w$, p. 18, emphasis added.

${ }^{63}$ Bork, “Legislative Intent,” pp. 45-46.

64 Kintner, $L H$, p. 286; and Cong. Rec., Apr. 8, 1890, p. 3148. 
competition in trade in old times in England, to international and interstate commerce in the United States." 65

Bork's interpretation of the common-law basis of the Sherman Act strains the language of the law and minimizes evidence that Sherman exercised little influence on the final bill. In spite of Bork's assertions to the contrary, the phrase "restraint of trade and commerce" most probably meant what it said: restraints on production and of commerce referred to activities that prevented others, by "unlawful" methods, from producing or selling their goods or services.

\section{Jurisdictional Issues}

The most frequently expressed doubts over Sherman's bill focused on the constitutional authority for national legislation on trusts. The debate highlighted the fascinating issues of federalism raised when corporations, organized under state law, engaged in economic activity beyond state boundaries. Those issues shaped a perception of the need for national antitrust legislation that helps explain why the common law became the basis of the Sherman Act, throwing further doubt on the consumer-welfare perspective.

Jurisdictional questions repeatedly threatened the proposed legislation and shed light on the federal political structure as a source of the trust problem. Senators John H. Reagan (D., Texas) and James Z. George (D., Mississippi) questioned the constitutional basis for federal antitrust legislation. ${ }^{66}$ Part of George's objections seemed directed toward concerns over centralization of power expressed by Senator James K. Jones (R., Arkansas) ${ }^{67}$ In addition, Senator Vest challenged the novelty of basing federal jurisdiction on diversity of citizenship of corporate shareholders rather than of litigants in a dispute. ${ }^{68}$ These debates danced around the issue of how to respond to interstate and international economic activity by state-chartered corporations. Sherman argued that the design of the trust device to evade state corporation law required a national response. ${ }^{69}$ Senator Henry M. Teller (R.,

\footnotetext{
${ }^{65}$ Kintner, $L H$, p. 293; and Cong. Rec., Apr. 8, 1890, p. 3152. Also see Hoar's comments in Kintner, $L H$, p. 282; and Cong. Rec., Apr. 8, 1890, p. 3146.

${ }^{66}$ Reagan objected to using the taxing power and favored relying on the commerce clause. Kintner, $L H$, p. 72; and Cong. Rec., Jan. 25, 1889, p. 1169. George argued the reverse, interpreting the commerce clause authority narrowly. Kintner, $L H$, pp. 83, 84-86, 100, 102, 104; Cong. Rec., Feb. 4, 1889, pp. 1460-61; and Cong. Rec., Feb. 27, 1890, pp. 1768-69.

${ }^{67}$ Kintner, $L H$, p. 76; and Cong. Rec., Feb. 4, 1889, p. 1457. Also see Senator Hiscock's comments in Kintner, $L H$, p. 142; and Mar. 21, 1890, p. 2467.

${ }^{68}$ Kintner, LH, p. 135; and Cong. Rec., Mar. 21, 1890, p. 2464. Senator Platt echoed these arguments (Kintner, $L H$, pp. 201-2; and Cong. Rec., Mar. 25, 1890, p. 2607), whereas Senator David Turpie (D., Indiana) responded to them (Kintner, $L H$, p. 151; and Cong. Rec., Mar. 24, 1890 , p. 2557).

${ }^{69}$ Kintner, $L H$, p. 128; and Cong. Rec., Mar. 21, 1890, p. 2462. Indeed, Sherman's original bill sought to punish corporate violations by forfeiture of the charter-without explaining how the
} 
Colorado) challenged the effectiveness of Sherman's bill in apparent recognition of innovations in state law creating the holding company and granting broad merger authority. ${ }^{70}$ Representative William L. Wilson (D., West Virginia) picked up this theme to argue that if corporations were the problem, the solution lay with the states, not Congress. ${ }^{71}$

The economic problem raised by the federal political structure elicited proposed solutions ranging from relying on state corporation law to enacting strong federal legislation to compromising on something in between. A number of senators shared with Teller the belief that revision of state corporation laws could address the problem. "Every corporation that is created is created at the will of a State, and the State can put upon it just such conditions as it sees fit."72 Others sided with Sherman in believing that only the national government could effectively regulate corporations engaged in economic activity spanning several states. ${ }^{73}$ Still others advocated joint action at the state and federal levels. Senator Richard Coke (D., Texas) introduced a substitute for Sherman's bill that declared illegal the interstate transport of any trust-produced product from a state declaring such trust illegal. ${ }^{74}$ This feature simultaneously recognized the authority of state corporate law and its limitations under the commerce clause.

This debate helps explain the common-law language of the Sherman Act, and thereby challenges the consumer-welfare hypothesis. Legislators apparently believed that state law could deal with an organization's objectionable business practices if a single state contained the firm's economic activity. But states were powerless when the firm's activity expanded beyond the legal domicile. The absence of a federal common

federal government could remove a state franchise; see Kintner, $L H$, p. 64, and comment by Senator Hoar (Kintner, LH, p. 173; and Cong. Rec., Mar. 24, 1890, pp. 2567-68).

${ }^{70}$ Kintner, $L H$, p. 159; and Cong. Rec., Mar. 24, 1890, p. 2560. See Hovenkamp, Enterprise, pp. 241-67, for an insightful discussion of the relationship between corporation law and the common law on trade restraints as an antitrust response. An account of New Jersey's innovation in corporate law at this time appears in Grandy, New Jersey, chap. 3.

${ }^{71}$ Kintner, $L H$, p. 308; and Cong. Rec., May 1, 1890, p. 4093. Also see his comments at Kintner, LH, p. 313; and Cong. Rec., May 1, 1890, p. 4097.

72 Kintner, $L H$, p. 182; and Cong. Rec., Mar. 24, 1890, pp. 2571-72; also Kintner, LH, p. 158; and Cong. Rec., Mar. 24, 1890, p. 2560. For a fascinating development of this argument see McCurdy, "Sugar Decision." Also see comments by Senators George (Kintner, LH, p. 83; and Cong. Rec., Feb. 4, 1889, p. 1460) and Hiscock (Kintner, LH, p. 142; and Cong. Rec., Mar. 21, 1890 , p. 2468).

${ }^{73}$ Kintner, LH, p. 176; and Cong. Rec., Mar. 24, 1890, p. 2569; also see Sherman's comments in Kintner, $L H$, pp. 122-23; and Cong. Rec., Mar. 21, 1890, p. 2460. Also comments by Senator Jones (Kintner, $L H$, p. 76; and Feb. 4, 1889, p. 1457) and Representative Heard (Kintner, $L H$, pp. 319-20; and Cong. Rec., May 1, 1890, p. 4101).

${ }^{74}$ Kintner, $L H$, p. 209; and Cong. Rec., Mar. 25, 1890, p. 2614. See also statements by Senator Reagan (Kintner, LH, pp. 145, 190; Cong. Rec., Mar. 21, 1890, pp. 2469-70; and Cong. Rec., Mar. 25, 1890, p. 2601) and Representative David B. Culberson (D., Texas) (Kintner, LH, pp. 295, 305; and Cong. Rec., May 1, 1890, p. 4091). 
law meant that the national government would also fail to reach objectionable actions. The Sherman Act provided the basis for a national-level response by adopting the common law familiar at the state level, adding criminal sanctions, and specifying civil remedies for those injured. ${ }^{75}$ We have seen that a common-law basis for the Sherman Act undermines the consumer-welfare hypothesis because the common law addressed the behavior of producers without reference to consumers. ${ }^{76}$

\section{CONCLUSION}

Twenty-five years ago Robert Bork argued that the Sherman Antitrust Act reflected a consumer-welfare standard. For Bork, direct policy statements in the bills and debates, the type of activities Congress found objectionable, the preservation of efficiency-promoting combinations, an artificial statement of the common law, and the lack of any clearly expressed alternative to consumer welfare supported this view. The consumer-welfare standard condemns actions that tend to restrict output and raise prices without compensating reductions in costs. But to the extent that costs fall by more than the deadweight loss to consumers, the standard sanctions such activity. Importantly, the consumerwelfare standard provides a clear and cogent set of rules that courts can apply in antitrust cases, and no other view of antitrust accomplishes that task as well. ${ }^{77}$

But the legislative history of the Sherman Act fails to support the consumer-welfare hypothesis and suggests that Congress focused its concern on producer behavior. The Congressional debates reveal that Sherman's proconsumer, price-regulation language met with serious objections and failed to survive. Debate on the "monopolization" offense of Section 2 gave rise to a definition of monopoly that made the exclusion of competitors a necessary condition. Resort to common-law language raised a presumption of a focus on producers, rather than consumers, and the economic implications of the federal political structure help explain reliance on that language. Rejection of the consumer-welfare hypothesis for the Sherman Act's origins, in favor of a view that Congress laid the foundations for regulating business behavior, may muddy the waters of antitrust policy, but it clarifies some of antitrust's stormy history.

\footnotetext{
75 Thorelli, Federal Antitrust, pp. 229, 571; and Letwin, Law, p. 52.

${ }^{76}$ Posner, Antitrust Law, p. 24, objected to the common-law basis of antitrust explicitly: "The Sherman Act did not enact the common law of restraint of trade. A better guide to interpreting the Sherman Act is the economic analysis of monopoly."

7 Hovenkamp, “Antitrust Policy," p. 234; and Hovenkamp, "Technology," p. 1020.
} 


\section{Appendix: Chronology of Senator Sherman's Antitrust Bill}

August 14, 1888 (50th Congress)

Senator Reagan introduces S. 3440, defining and declaring trusts illegal.

Senator Sherman introduces S. 3445.

Neither bill acted upon.

December 4, 1889 (51st Congress)

Sherman introduces S. 1 (identical to S. 3445).

January 14,1890

S. 1 reported by Senate Finance Committee.

February 27, 1890

Debate on S. 1. Reagan introduces his bill as amendment.

March 21 to 27, 1890

Senate Debate.

March 27, 1890

S. 1 referred to Senate Judiciary Committee.

April 2, 1890

Judiciary Committee reports revised version of S. 1 .

April 8, 1890

Senate passes $S .1$ by vote of $52-1$.

April 25, 1890

May 1,1890

House Judiciary Committee reports S. 1.

House debate.

June 11,1890

First conference committee report.

June 20,1890

Second conference committee report. House passes S. 1 by vote of 242-0. July 2,1890

President Harrison signs Sherman Act.

\section{REFERENCES}

Blake, Harlan M., and William K. Jones, "In Defense of Antitrust," Columbia Law Review, 65 (Mar. 1965), pp. 377-400.

Blake, Harlan M., and William K. Jones, "Toward a Three-Dimensional Antitrust Policy," Columbia Law Review, 65 (Mar. 1965), pp. 422-66.

Bork, Robert H., "Contrasts in Antitrust Theory: I," Columbia Law Review, 65 (Mar. 1965), pp. 401-16.

Bork, Robert H., "Legislative Intent and the Policy of the Sherman Act," Journal of Law \& Economics, 9 (Oct. 1966), pp. 7-48.

Bork, Robert H., "Antitrust and Monopoly, The Goals of Antitrust Policy," AER Papers and Proceedings, 57 (May 1967), pp. 242-53.

Bork, Robert H., The Antitrust Paradox, A Policy at War with Itself (New York, 1978).

Bork, Robert H., and Ward S. Bowman, Jr., "The Crisis in Antitrust," Columbia Law Review, 65 (Mar. 1965), pp. 363-76.

Carey, Robin, "The Sherman Act: What Did Congress Intend?" The Antitrust Bulletin, 34 (Summer 1989), pp. 337-50. 
Chandler, Alfred D., Jr., The Visible Hand: The Managerial Revolution in American Business (Cambridge, MA, 1977).

Congressional Record (Washington, DC, various dates).

Dewey, Donald, Monopoly in Economics and Law (Chicago, 1959).

Dewey, Donald, "The Economic Theory of Antitrust: Science or Religion?" Virginia Law Review, 50 (Apr. 1964), pp. 413-34.

DiLorenzo, Thomas J., "The Origins of Antitrust: An Interest-Group Perspective," International Review of Law and Economics, 5 (June 1985), pp. 73-90.

DiLorenzo, Thomas J., and Jack C. High, "Antitrust and Competition, Historically Considered," Economic Inquiry, 26 (July 1988), pp. 423-35.

Flynn, John J., "The Reagan Administration's Antitrust Policy, 'Original Intent' and the Legislative History of the Sherman Act," The Antitrust Bulletin, 33 (Summer 1988), pp. 259-307.

Freyer, Tony, Regulating Big Business: Antitrust in Great Britain and America, 1880-1990 (Cambridge, 1992).

Grandy, Christopher, New Jersey and the Fiscal Origins of Modern American Corporation Law (New York, 1993).

Hazlett, Thomas W., "The Legislative History of the Sherman Act Re-examined," Economic Inquiry, 30 (Apr. 1992), pp. 263-76.

Hovenkamp, Herbert, "Distributive Justice and the Antitrust Laws," George Washington Law Review, 51 (Nov. 1982), pp. 1-31.

Hovenkamp, Herbert, "Technology, Politics, and Regulated Monopoly: An American Historical Perspective," Texas Law Review, 62 (Apr. 1984), pp. 1263-1312.

Hovenkamp, Herbert, "Antitrust Policy After Chicago," Michigan Law Review, 84 (Nov. 1985), pp. 213-84.

Hovenkamp, Herbert, "Chicago and Its Alternatives," Duke Law Journal, 1986 (Dec. 1986), pp. 1014-29.

Hovenkamp, Herbert, "Antitrust's Protected Classes," Michigan Law Review, 88 (Oct. 1989), pp. $1-48$.

Hovenkamp, Herbert, Enterprise and American Law 1836-1937 (Cambridge, MA, 1991).

Kintner, Earl W., The Legislative History of the Federal Antitrust Laws and Related Statutes (New York and London, 1978), vol. 1.

Lamoreaux, Naomi R., The Great Merger Movement in American Business, 1895-1904 (New York, 1985).

Lande, Robert H., "Wealth Transfers as the Original and Primary Concern of Antitrust: The Efficiency Interpretation Challenged," Hastings Law Journal, 34 (Sept. 1982), pp. 65-151.

Letwin, William L., "Congress and the Sherman Antitrust Law: 1887-1890," The University of Chicago Law Review, 23 (Winter 1956), pp. 221-58.

Letwin, William L., Law and Economic Policy in America: The Evolution of the Sherman Antitrust Act (Chicago, 1965).

Libecap, Gary D., "The Rise of the Chicago Packers and the Origins of Meat Inspection and Antitrust," Economic Inquiry, 30 (Apr. 1992), pp. 242-62.

McCraw, Thomas K., "Rethinking the Trust Question," in Thomas K. McCraw, ed., Regulation in Perspective: Historical Essays (Cambridge, MA, 1981), pp. 1-55.

McCurdy, Charles W., "The Knight Sugar Decision of 1895 and the Modernization of American Corporation Law, 1869-1903," Business History Review, 53 (Autumn 1979), pp. 304-42.

May, James, "Antitrust in the Formative Era: Political and Economic Theory in Constitutional and Antitrust Analysis, 1880-1918," Ohio State Law Journal, 50 (1989), pp. 257-395. 
Millon, David, "The Sherman Act and the Balance of Power," Southern California Law Review, 61 (July 1988), pp. 1219-92.

Posner, Richard A., Antitrust Law: An Economic Perspective (Chicago, 1976).

Scherer, F. M., "Efficiency, Fairness, and the Early Contributions of Economists to the Antitrust Debate," Washburn Law Journal, 29 (Winter 1990), pp. 243-55.

Schmidt, Ingo L. O., and Jan B. Rittaler, A Critical Evaluation of the Chicago School of Antitrust Analysis (Dordrecht, The Netherlands, 1989).

Sklar, Martin J., The Corporate Reconstruction of American Capitalism 1890-1916: The Market, the Law, and Politics (Cambridge, 1988).

Taft, William Howard, The Anti-Trust Act and the Supreme Court (New York, 1914; reprint 1970).

Thorelli, Hans B., The Federal Antitrust Policy: Origination of an American Tradition (Stockholm, 1954).

Trebilcock, Michael J., The Common Law of Restraint of Trade: A Legal and Economic Analysis (Toronto, 1986). 